\title{
Studies on Regional Green Development Based on Social Network Analysis
}

\author{
Yuan Huang ${ }^{1}$, Zongling Wang $^{1}$, Yi Zeng 1,* \\ ${ }^{1}$ China National Institute of Standardization, No.4, Zhichun Road, Haidian District, Beijing 100191, China
}

\begin{abstract}
Under the guidance of five development concepts, we should grasp regional overall economic, innovation, and traffic associated structure macroscopically, and analyze cities' status and role within the region when planning the regional green design. Through systematically considering regional overall structure, relationship between subjects and individual differences without prejudice to the ecological environment, it can play the greatest role of traffic led, city led, and market led, which can achieve regional green development. We build the traffic interaction network model, economic correlation network model, and innovation-driven network model to analyze network structures, identify key nodes and provide methodological guidance for regional green development plan. We bring Beijing-Tianjin-Hebei Urban Agglomeration for the case study and draw the following conclusions. The traffic interaction network is closer than the economic correlation network and the innovation-driven network, and the economic correlation network is closer than the innovation-driven network. The three networks all have a high degree of centralization, which means there is a great difference among cities. Beijing, Tianjin, Shijiazhuang develop relatively well, however, Chengde, Hengshui and Zhangjiakou relatively fall behind. Dezhou has a foundation to promote transportation integration and lacks the economic momentum and innovation driven. Chengde should increase the degree of innovation and communication to build connection with other cities.
\end{abstract}

\section{Introduction}

Green development and sustainable development is the trend of times in the world. The essence of green development is to reduce the excessive consumption of resources, strengthen environmental protection and ecological management, and pursue the sustainable development of economy, society and ecology. The environmental situation in China highlights the necessity and urgency of green development and the construction of the ecological civilization. The five development concepts proposed in 2015 are innovation, coordination, green, opening up, and sharing.

\subsection{Regional green development}

The research of regional green development is always from the perspective of ecology[1], geography[2], economics[3], management[4], resource and energy utilization[5], Policy mechanism[6], and so on. In this paper, we think green and coordination complement each other and promote each other, so, we try to study regional green development from the perspective of structure analysis. The thirteenth Five-Year Plan raise coordinated regional development, including promoting the coordinated development of Beijing-Tianjin-Hebei and the development of the Yangtze River Economic belt. So, we will start with regional coordinated development, which includes regional economic, transport integration and innovation-driven interaction.

\subsection{Social network analysis}

Social network analysis (SNA) method is proposed by sociology master White (Harison White) since 1960s. It has developed in the fields of measurement, mathematical sociology, social psychology, graphic theory. It can be an effective measure of network structure, through the specific description of the variables included degree, average path length, betweenness and clustering coefficient[7]. The social network analysis is a set of theories and methods to analyze the structure of social relationship and its attributes. In the process of social network analysis, the structure of any social organization can be regarded as a network, the behavior of the network members is affected by their location in the network and the network embedding[8]. Through the social network analysis, we can reveal the deep social structure and its evolution under the complex social system. The social network analysis is a new perspective on the social relationship of many questions about interdisciplinary research on a different structure level. It can not only study the interaction of the micro-individual, but also can analyze the macro-social phenomenon and contribute to combine the relationship between the individual with the social system of large-scale structure.

\footnotetext{
* Corresponding author: zengyi@cnis.gov.cn
} 


\subsection{Social network analysis and regional green development}

Social network analysis has developed rapidly in recent twenty years. It has become a mature theory and method, which has been widely used in sociology, political science, anthropology, psychology[9], organizational management, mass communication, policy research and engineering science[10]. It can be said that the social network analysis method has been extended to almost all areas of human activities. Social network analysis of city association is becoming the main research which means an academic focus. Relevant scholars use social network analysis and take the city group as the research object, proposing relying on the city group as the main form of economic integration structure of the new urbanization strategy[11].

Based on the social network analysis theory, the regional green development should focus on the analysis of the location and role of the cities in the region, as well as the relationship between the subject and individual differences, under the premise of not break the ecological environment. Then we can maximize the traffic, city and market driven to realize the regional green development. Through the construction of involving regional traffic routes, industrial distribution parks social network, we can analyze the shortest path of the traffic and the coupling relationship of the industrial relevance, as well as mine the regional optimal network structure. By focusing on the large nodes to moderate regional social network, we can find the central cities at all levels. By using the social network model and the center degree, degree distribution, average path length, clustering coefficient, betweenness and other social network indicators, we can set reasonable standard value of regional industrial density, connectivity.

\section{Regional green development social network model}

This paper focused on the analysis of the regional linkage. Transportation is the basis of regional development, economic integration is the carrier of regional development, and innovation is the driving force of regional development. So we build the traffic interaction social network model, economic correlation social network model, and innovation-driven social network model. By studying the three network models, we can not only analyze the structure of the network and recognize the key nodes in the network, but also analyze the present situation of regional development and provide new ideas about promoting regional green development.

\subsection{Economic correlation social network model}

Regional economic integration is the important economic condition for the formation of urban agglomeration. City spatial interactions can strengthen the industrial cooperation among cities and regions, achieve the regional industrial division and cooperation, improve city connectivity, reduce logistics costs, improve transport efficiency, form industrial agglomeration, and eventually realize an efficient and healthy development of the entire region. The accurate measurement of the economic relationship among cities can understand the regional economic structure, and the depth analysis of the regional economic structure can understand the status of regional integration.

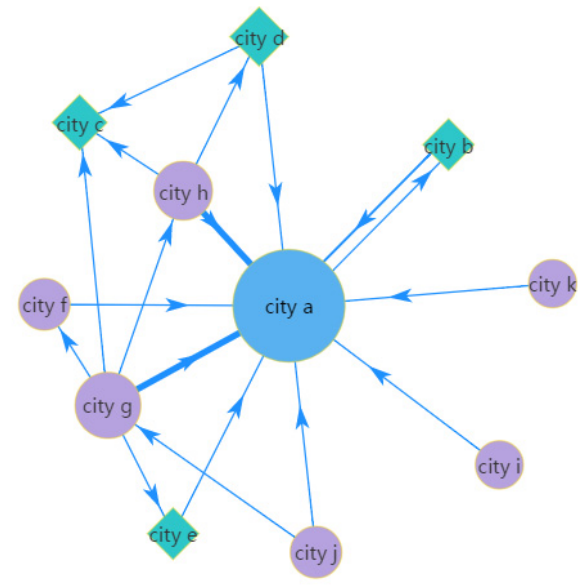

Fig. 1. A schematic of regional green development social network model.

The economic gravity theory suggests that the economic relations among cities have a similar law of universal gravitation[12-14], and there exist influence and interaction between cities in a certain area. The spatial interaction model is a classical model[14] for the study of urban interior among cities and regions.

$$
I_{i j}=G \frac{M_{i} M_{j}}{r^{b}}
$$

In the equation (1), $M_{i}, M_{j}$ represents the scale of city $\mathrm{i}$ and city $\mathrm{j}$ respectively, $\mathrm{r}$ represents the distance between city $i$ and city $j, G$ represents the gravitational coefficient. The scale of the city is always represented by the population of the city.

Because GDP can reflect the differences between cities' economic structure to a certain extent, so we take the GDP proportion to modify the gravity model. The equation (2) is the modified gravity model.

In the equation (2), $R_{i j}$ represents the economic relations between the city $\mathrm{i}$ and the city $\mathrm{j}, P_{i}, P_{j}$ are the city population of the city $\mathrm{i}$ and the city $\mathrm{j}$ respectively, $G_{i}, G_{j}$ are the GDP of the city $\mathrm{i}$ and the city $\mathrm{j}$ respectively, $D_{i j}$ represents the distance between the city $\mathrm{i}$ and the city $\mathrm{j}, k_{i j}$ represents the contribution rate of the city $i$ to the city $\mathrm{j}[15]$.

$$
R_{i j}=k_{i j} \frac{\sqrt{P_{i} \times G_{i}} \times \sqrt{P_{j} \times G_{j}}}{D_{i j}^{2}}
$$

In the directed economic association weighted network model, we take the cities in the region as the nodes and the value of economic relations among cities 
as the weight of edges. The value of the cities' relationship is calculated by the modified gravity model. In practical applications, we take the railway mileage between the two cities as their distance between them. The more closely the economic ties between the cities, the greater the economic association value is. If the value is less than 1 between the two cities, indicating the economic relationship between the two cities is very weak, so we regard there is no economic relationship between them, which also means there is no edge between them. As shown in Fig. 1., the city a points to the city $b$ indicates that the city a has economic association to city $\mathrm{b}$ and economic association value is no less than 1 . The edge that the city g points to the city $\mathrm{a}$ is thicker indicates that the city $\mathrm{g}$ has a greater economic association value to the city a.

\subsection{Innovation-driven social network model}

The development of the Internet greatly promotes the development of economy and society, and constantly changes the way of the economic development and people's behavior. With the extensive application of new generation of information technology, the number of the Internet users continues to increase. The Internet is fast penetrating to more and more industries. The innovation using the Internet technology emerges an endless stream. The Internet thinking was proposed in 2015 had become a new driving mode of innovation development, which taking the user as the core and the Internet as a channel. The innovation diffusion network model also follows the evaluation criteria of the social network analysis distance and the shortest path length [16]. In the gravity model, the number of the urban population will be changed into the number of the Internet users. By this way, it can reflect the driving effect of the Internet to the economy and the role of the innovation driven to a certain extent. The $R_{i j}$ in the model represents the innovation driving function of the city $i$ to city $j$. In the same way, we take the cities as nodes. The edges represent there have the innovation-driven between the two cities and the innovation-driven value no less than 1 . The thickness of the edges represents the weight of the edges, which is indicated by the innovation-driven value. In the established the directed regional innovation weighted network model as shown in Fig. 1., the city a points to the city $b$ indicates that the city a has an innovationdriven to the city $b$, and the edge that the city g points to the city $\mathrm{a}$ is thicker indicates that the city $\mathrm{g}$ has a strong innovation-driven to the city a.

\subsection{Regional green development social network analysis}

Through the social network analysis, we can get the global network structure, local network structure, node centrality and edge length intuitively.

The network density refers to the connection degree between the various members of the network. The network density is an important index to depict the overall network structure, and its numerical value is the actual relationship number compared to the theory possible relationship number of the network (complete graph). The more links between the members, the greater the density of the network.

The network diameter indicates the maximum value of the shortest distance between any two nodes in a network, which is negatively associated with the network transmission efficiency. The larger the network diameter, the lower the transmission efficiency of the network, and vice versa.

The average path length is the average value of the distance between all nodes, which reflects the overall characteristics of the network. The average path length is negatively correlated with the convenient level of transmission. The smaller the average path length, the more efficient on the network elements[17].

Real world networks have been shown to separate into logical clusters in which nodes are tightly connected to each other inside the module and loosely connected to nodes which are outside of their module. Newman's modularity is currently the most widely used metric to measure how modular a network is[18-19].

Clustering coefficients represent the local aggregation level of the network. If a node $i$ has $k_{i}$ adjacent nodes, the actual number of existence relationship between the adjacent nodes is $E_{i}$, and the node clustering coefficient is $E_{i}$ compared with the number of edges that the complete graph composed of the adjacent nodes[20]. The clustering coefficient mainly reflects the local nature of the network, and it is positively related to the local aggregation level of the node $\mathrm{i}$.

Degree is the simplest and most important property of the network node. The degree $\mathrm{k}$ of a node $\mathrm{i}$ is defined as the number of nodes connected to it. Therefore, from the intuitive point of view, the greater the degree of a node, the more important it is. In the directed graph, the degree of a node can be divided into two kinds, which are in degree and out degree. The in degree of the node $i$ is defined as the number of nodes pointing to the node $i$. The out degree of the node $i$ is defined as the number of nodes that the node $i$ pointing to. The bigger the degree is, the more relevance and the higher the importance is.

Node Closeness Centrality indicates how long it will take for the information from a node $u$ to reach other nodes in the network.

Node Betweenness Centrality indicates how often a node is found on a shortest path between two nodes in the network[20].

\section{Case studies}

This paper chose Beijing-Tianjin-Hebei urban agglomeration as the research case. On April 30, 2015, the Political Bureau of the CPC Central Committee held a meeting to consider the "Beijing-Tianjin-Hebei coordinated development plan". Outline pointed out that promoting the coordinated development of BeijingTianjin-Hebei region is a major national strategy. The plan aims at orderly relocating all non-essential 
functions from the national capital Beijing, to its neighboring locations. The move calls for adjusting the economic structure and rationalizing space utilization while exploring a new mode of optimized integrated development in a region with a dense population. The broad region covers Beijing, Tianjin and 11 prefectural cities in the Hebei Province. Environmental protection, integrated transport services, and industrial upgrading and relocation are the three focus sectors. The Outline of the plan for coordinated development for the BeijingTianjin-Hebei Region, released in April 2015, highlights development-oriented solutions to ecological, social, and economic problems, and incorporates considerations of environmental sustainability.

Beijing-Tianjin-Hebei is a dual core structure, which is different from the Pearl River Delta and the Yangtze River Delta. The key points of the relationship among the Beijing-Tianjin-Hebei lie in the relationship between Beijing and Tianjin. "In support of Shandong Dezhou construct industry undertaking, transformation of scientific and technological achievements, high-quality agricultural products supply, labor delivery base and important ecological function areas of south BeijingTianjin-Hebei" was clearly put forward in the "Beijing Tianjin Hebei collaborative development plan". Dezhou as the only city in Shandong Province into the planning, indicating "a region and four bases" strategic position was officially established.

Therefore, this study thinks that Beijing-TianjinHebei urban agglomeration contains Beijing, Tianjin, Baoding, Zhangjiakou, Qinhuangdao, Tangshan, Shijiazhuang, Langfang, Xingtai, Handan, Hengshui, Cangzhou, Chengde, Dezhou, total 14 cities. The following case study will consist of including Dezhou and exclude Dezhou two situations.

\subsection{Traffic interaction social network model}

According to Section 2.1, we establish the traffic interaction social network model of Beijing-TianjinHebei urban agglomeration. The data comes from http://www.12306.cn/. By using the Gephi, which is a network analysis tool, we get the model indicators of two situations, which are included Dezhou and excluded Dezhou (Table 1.). The network graph is shown in fig. 2. The weighted degree, weighted In-Degree, weighted Out-Degree, Closeness Centrality, Betweenness Centrality and Eigenvector Centrality of the nodes are ordered from high to low in the Table 1,2,3.

When we exclude Dezhou, the average degree and the average weighted degree of the network is decreasing. It indicates that Dezhou has a close interaction with other cities among Beijing-Tianjin-Hebei urban agglomeration, which means that putting Dezhou into the planning can promote transport integration of Beijing-Tianjin-Hebei.

The network density and the average clustering coefficient are high and the average path length is small. It indicated that transport integration of Beijing-TianjinHebei develops well in general. The modularity class indicates a high degree of centralization. However, there exist a great difference between cities, which is Beijing, Tianjin and Shijiazhuang develop well, while Hengshui and Zhangjiakou relatively fall behind, and Baoding, Chende and Cangzhou are close to other cities.

Table 1. Traffic interaction social network analysis.

\begin{tabular}{|c|c|c|}
\hline Index & $\begin{array}{l}\text { Beijing-Tianjin- } \\
\text { Hebei urban } \\
\text { agglomeration }\end{array}$ & $\begin{array}{l}\text { Beijing-Tianjin- } \\
\text { Hebei urban } \\
\text { agglomeration } \\
\text { (exclude Dezhou) }\end{array}$ \\
\hline Nodes & 14 & 13 \\
\hline Edges & 169 & 145 \\
\hline $\begin{array}{l}\text { Average } \\
\text { degree }\end{array}$ & 12 & 11 \\
\hline $\begin{array}{c}\text { Average } \\
\text { weighted } \\
\text { degree }\end{array}$ & 328 & 313 \\
\hline $\begin{array}{c}\text { Network } \\
\text { density }\end{array}$ & 0.929 & 0.929 \\
\hline $\begin{array}{l}\text { Network } \\
\text { diameter }\end{array}$ & 2 & 2 \\
\hline $\begin{array}{l}\text { Average } \\
\text { clustering } \\
\text { coefficient }\end{array}$ & 0.933 & 0.933 \\
\hline $\begin{array}{l}\text { Average path } \\
\text { length }\end{array}$ & 1.071 & 1.071 \\
\hline Modularity 1 & $\begin{array}{c}\text { Beijing, } \\
\text { Shijiazhuang, } \\
\text { Baoding, Handan, } \\
\text { Xingtai, } \\
\text { Zhangjiakou, } \\
\text { Chende, }\end{array}$ & $\begin{array}{c}\text { Beijing, Tianjin, } \\
\text { Tangshan, } \\
\text { Qinhuangdao, } \\
\text { Zhangjiakou, } \\
\text { Chende, Cangzhou, } \\
\text { Langfang } \\
\end{array}$ \\
\hline Modularity2 & $\begin{array}{l}\text { Tianjin, Tangshan, } \\
\text { Qinhuangdao, } \\
\text { Dezhou, Cangzhou, } \\
\text { Langfang, Hengshui }\end{array}$ & $\begin{array}{c}\text { Shijiazhuang, } \\
\text { Handan, Xingtai, } \\
\text { Baoding, Hengshui }\end{array}$ \\
\hline $\begin{array}{l}\text { Nodes with } \\
\text { greater } \\
\text { weighted } \\
\text { degree }\end{array}$ & $\begin{array}{c}\text { Beijing, Tianjin, } \\
\text { Shijiazhuang, } \\
\text { Baoding Tangshan, } \\
\text { Handan }\end{array}$ & $\begin{array}{c}\text { Beijing, Tianjin, } \\
\text { Shijiazhuang, } \\
\text { Baoding Tangshan, } \\
\text { Handan }\end{array}$ \\
\hline $\begin{array}{l}\text { Nodes with } \\
\text { greater } \\
\text { weighted In- } \\
\text { Degree }\end{array}$ & $\begin{array}{c}\text { Beijing, Tianjin, } \\
\text { Shijiazhuang, } \\
\text { Baoding, Dezhou, } \\
\text { Tangshan }\end{array}$ & $\begin{array}{c}\text { Beijing, Tianjin, } \\
\text { Shijiazhuang, } \\
\text { Baoding, Handan, } \\
\text { Xingtai }\end{array}$ \\
\hline $\begin{array}{l}\text { Nodes with } \\
\text { greater } \\
\text { weighted } \\
\text { Out-Degree } \\
\end{array}$ & $\begin{array}{c}\text { Beijing, Tianjin, } \\
\text { Shijiazhuang, } \\
\text { Baoding, Tangshan, } \\
\text { Handan } \\
\end{array}$ & $\begin{array}{c}\text { Beijing, } \\
\text { Shijiazhuang, } \\
\text { Tianjin, Baoding, } \\
\text { Tangshan, Handan }\end{array}$ \\
\hline $\begin{array}{l}\text { Nodes with } \\
\text { greater } \\
\text { Closeness } \\
\text { Centrality }\end{array}$ & $\begin{array}{c}\text { Baoding, Chende, } \\
\text { Cangzhou }\end{array}$ & $\begin{array}{c}\text { Chende, Baoding, } \\
\text { Cangzhou }\end{array}$ \\
\hline $\begin{array}{l}\text { Nodes with } \\
\text { greater } \\
\text { Betweenness } \\
\text { Centrality } \\
\end{array}$ & $\begin{array}{c}\text { Beijing, Tianjin, } \\
\text { Shijiazhuang, } \\
\text { Handan, Xingtai, } \\
\text { Langfang } \\
\end{array}$ & $\begin{array}{c}\text { Beijing, } \\
\text { Shijiazhuang, } \\
\text { Tianjin, Handan, } \\
\text { Xingtai, Langfang }\end{array}$ \\
\hline
\end{tabular}



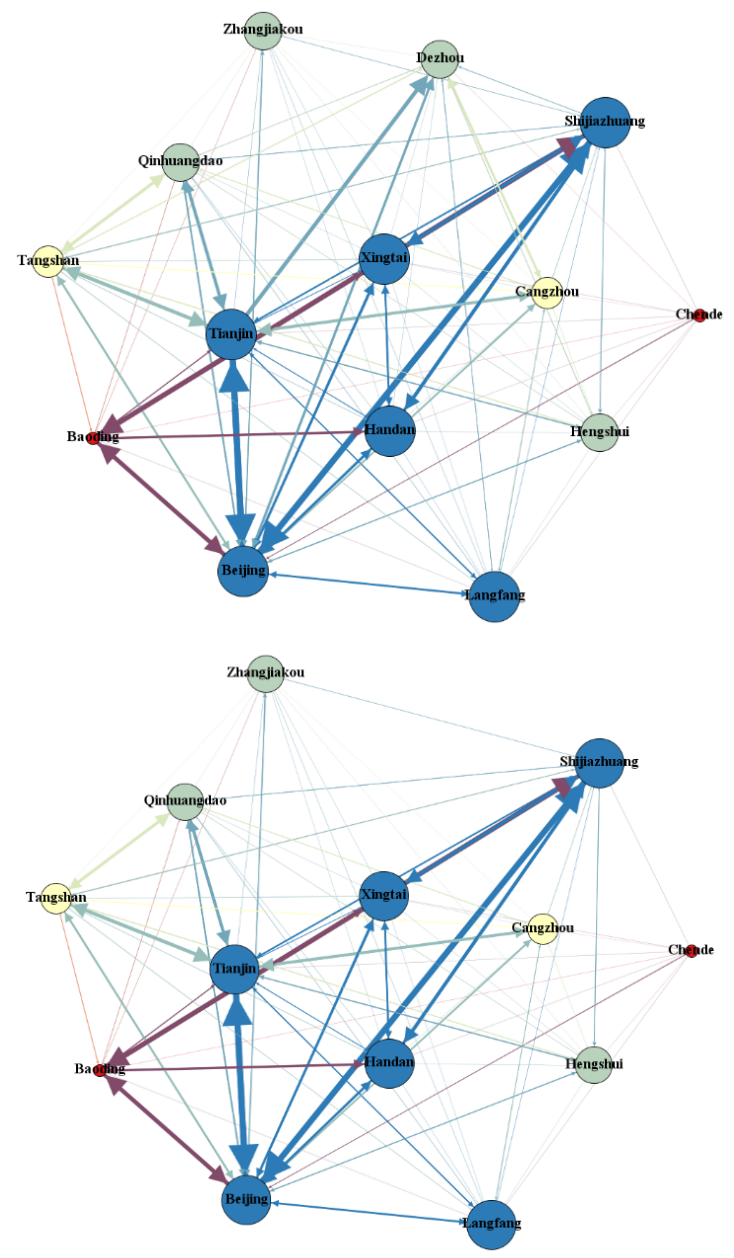

Fig. 2. (a) Traffic interaction network graph of Beijing-TianjinHebei urban agglomeration; (b) Traffic interaction network graph of Beijing-Tianjin-Hebei urban agglomeration (exclude Dezhou).

\subsection{Economic correlation social network model}

According to section 2.2, we calculate the economic association value by modified gravity model, and then we establish the economic association social network model of Beijing-Tianjin-Hebei urban agglomeration. The data comes from China city statistical yearbook 2015. By using Gephi, a network analysis tool, we get the model indicators of two situations, which are included Dezhou and excluded Dezhou (Table 2). The network graph is shown in fig. 3 .

When we exclude Dezhou, the average weighted degree, the density, the average clustering coefficient and the average path length of the network is increasing, which indicates that Dezhou doesn't have a close economic interaction with other cities among BeijingTianjin-Hebei urban agglomeration.

The network density and the average clustering coefficient is lower than the traffic interaction network, the network diameter and the average path length is higher than the network diameter, which indicates that the transport integration develop well than the economic correlation of Beijing-Tianjin-Hebei. The modularity class indicates a high degree of centralization. However, there exists a great difference between cities, which is Beijing, Tianjin, Shijiazhuang develop well, Hengshui, Zhangjiakou and Chende relatively backward, and Handan, Xingtai, Baoding, Tangshan, Shijiazhuang and Tianjin are close to other cities.

Table 2. Economic correlation social network analysis.

\begin{tabular}{|c|c|c|}
\hline Index & $\begin{array}{l}\text { Beijing-Tianjin- } \\
\text { Hebei urban } \\
\text { agglomeration }\end{array}$ & $\begin{array}{l}\text { Beijing-Tianjin- } \\
\text { Hebei urban } \\
\text { agglomeration } \\
\text { (exclude Dezhou) }\end{array}$ \\
\hline Nodes & 14 & 13 \\
\hline Edges & 39 & 35 \\
\hline $\begin{array}{l}\text { Average } \\
\text { degree }\end{array}$ & 3 & 3 \\
\hline $\begin{array}{c}\text { Average } \\
\text { weighted } \\
\text { degree } \\
\end{array}$ & 26 & 28 \\
\hline $\begin{array}{l}\text { Network } \\
\text { density }\end{array}$ & 0.214 & 0.224 \\
\hline $\begin{array}{l}\text { Network } \\
\text { diameter }\end{array}$ & 3 & 3 \\
\hline $\begin{array}{l}\text { Average } \\
\text { clustering } \\
\text { coefficient }\end{array}$ & 0.625 & 0.631 \\
\hline $\begin{array}{l}\text { Average path } \\
\text { length }\end{array}$ & 1.728 & 1.75 \\
\hline Modularity1 & $\begin{array}{c}\text { Beijing, Baoding, } \\
\text { Zhangjiakou, } \\
\text { Chende, } \\
\text { Shijiazhuang, } \\
\text { Xingtai, Handan }\end{array}$ & $\begin{array}{c}\text { Tianjin, } \\
\text { Qinhuangdao, } \\
\text { Tangshan, Langfang, } \\
\text { Cangzhou, Hengshui }\end{array}$ \\
\hline Modularity2 & $\begin{array}{c}\text { Tianjin, } \\
\text { Qinhuangdao, } \\
\text { Tangshan, } \\
\text { Langfang, } \\
\text { Cangzhou, } \\
\text { Hengshui, Dezhou }\end{array}$ & $\begin{array}{c}\text { Shijiazhuang, } \\
\text { Handan, Xingtai, } \\
\text { Baoding, Hengshui }\end{array}$ \\
\hline $\begin{array}{l}\text { Nodes with } \\
\text { greater } \\
\text { weighted } \\
\text { degree }\end{array}$ & $\begin{array}{c}\text { Beijing, Tianjin, } \\
\text { Langfang, } \\
\text { Tangshan, } \\
\text { Shijiazhuang, } \\
\text { Baoding }\end{array}$ & $\begin{array}{l}\text { Beijing, Baoding, } \\
\text { Zhangjiakou, } \\
\text { Chende, } \\
\text { Shijiazhuang, } \\
\text { Xingtai, Handan }\end{array}$ \\
\hline $\begin{array}{l}\text { Nodes with } \\
\text { greater } \\
\text { weighted In- } \\
\text { Degree } \\
\end{array}$ & $\begin{array}{l}\text { Langfang, Tianjin, } \\
\text { Beijing, Tangshan, } \\
\text { Shijiazhuang, } \\
\text { Baoding }\end{array}$ & $\begin{array}{c}\text { Langfang, Tianjin, } \\
\text { Beijing, Tangshan, } \\
\text { Shijiazhuang, } \\
\text { Baoding }\end{array}$ \\
\hline $\begin{array}{l}\text { Nodes with } \\
\text { greater } \\
\text { weighted } \\
\text { Out-Degree }\end{array}$ & $\begin{array}{c}\text { Beijing, Tianjin, } \\
\text { Tangshan, } \\
\text { Shijiazhuang, } \\
\text { Handan, Xingtai }\end{array}$ & $\begin{array}{c}\text { Beijing, Tianjin, } \\
\text { Tangshan, } \\
\text { Shijiazhuang, } \\
\text { Handan, Xingtai }\end{array}$ \\
\hline $\begin{array}{l}\text { Nodes with } \\
\text { greater } \\
\text { Closeness } \\
\text { Centrality }\end{array}$ & $\begin{array}{c}\text { Handan, Xingtai, } \\
\text { Baoding, Tangshan, } \\
\text { Shijiazhuang, } \\
\text { Tianjin }\end{array}$ & $\begin{array}{l}\text { Handan, Xingtai, } \\
\text { Baoding, Tangshan, } \\
\text { Shijiazhuang, Tianjin }\end{array}$ \\
\hline $\begin{array}{l}\text { Nodes with } \\
\text { greater } \\
\text { Betweenness } \\
\text { Centrality }\end{array}$ & $\begin{array}{l}\text { Beijing, } \\
\text { Shijiazhuang, } \\
\text { Tianjin }\end{array}$ & $\begin{array}{c}\text { Beijing, } \\
\text { Shijiazhuang, Tianjin }\end{array}$ \\
\hline
\end{tabular}




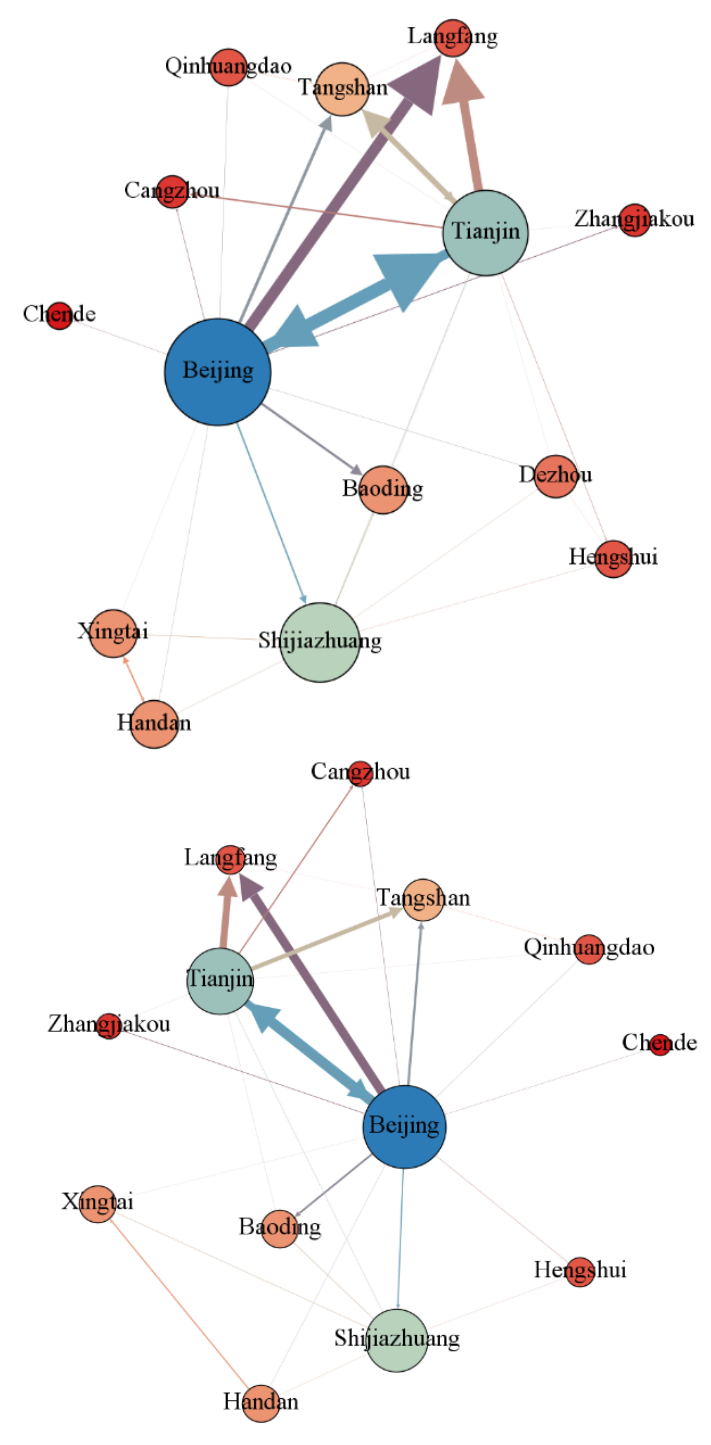

Fig. 3. (a) Economic correlation network graph of BeijingTianjin-Hebei urban agglomeration; (b) Economic correlation network graph of Beijing-Tianjin-Hebei urban agglomeration (exclude Dezhou).

\subsection{Innovation-driven social network model}

According to section 2.3, we calculate the innovationdriven value by modified gravity model, and then establish the innovation-driven social network model of Beijing-Tianjin-Hebei urban agglomeration. The data comes from China city statistical yearbook 2015. By using Gephi, a network analysis tool, we get the model indicators of two situations, which are included Dezhou and excluded Dezhou (Table 3), The network graph is shown in fig. 4.

When we exclude Dezhou, the average degree, the average weighted degree, the density, the average clustering coefficient of the network is increasing, which indicates that Dezhou doesn't have a close innovation interaction with other cities among Beijing-TianjinHebei urban agglomeration. Chengde doesn't has an innovation correlation with others cities, which indicates that it lacks of innovation driven.
The network density and the average clustering coefficient is lower than the traffic interaction network and, and the network diameter and the average path length is higher than the network diameter, which indicats that the transport integration develops well than economic correlation of Beijing-Tianjin-Hebei. The modularity class indicates a high degree of centralization. However, there exists a great difference between cities. Beijing, Tianjin and Shijiazhuang develop well, Chende, Hengshui, Zhangiiakou relatively fall behind, and Handan, Xingtai, Baoding, Tangshan, Shijiazhuang and Tianjin are close to other cities.

Table 3. Innovation-driven social network analysis.

\begin{tabular}{|c|c|c|}
\hline Index & $\begin{array}{l}\text { Beijing-Tianjin- } \\
\text { Hebei urban } \\
\text { agglomeration }\end{array}$ & $\begin{array}{l}\text { Beijing-Tianjin- } \\
\text { Hebei urban } \\
\text { agglomeration } \\
\text { (exclude Dezhou) }\end{array}$ \\
\hline Nodes & 13 & 12 \\
\hline Edges & 31 & 30 \\
\hline $\begin{array}{l}\text { Average } \\
\text { degree }\end{array}$ & 2 & 3 \\
\hline $\begin{array}{c}\text { Average } \\
\text { weighted } \\
\text { degree }\end{array}$ & 22 & 24 \\
\hline $\begin{array}{l}\text { Network } \\
\text { density }\end{array}$ & 0.199 & 0.227 \\
\hline $\begin{array}{l}\text { Network } \\
\text { diameter }\end{array}$ & 4 & 3 \\
\hline $\begin{array}{c}\text { Average } \\
\text { clustering } \\
\text { coefficient }\end{array}$ & 0.599 & 0.625 \\
\hline $\begin{array}{l}\text { Average } \\
\text { path length }\end{array}$ & 1.781 & 1.772 \\
\hline $\begin{array}{c}\text { Modularity } \\
1\end{array}$ & $\begin{array}{l}\text { Tianjin, Beijing, } \\
\text { Langfang, } \\
\text { Tangshan, } \\
\text { Baoding, } \\
\text { Cangzhou, } \\
\text { Zhangjiakou, } \\
\text { Qinhuangdao, } \\
\text { Dezhou }\end{array}$ & $\begin{array}{l}\text { Beijing, Tianjin, } \\
\text { Tangshan, } \\
\text { Qinhuangdao, } \\
\text { Baoding, } \\
\text { Zhangjiakou, } \\
\text { Cangzhou, } \\
\text { Langfang }\end{array}$ \\
\hline $\begin{array}{c}\text { Modularity } \\
2\end{array}$ & $\begin{array}{c}\text { Shijiazhuang, } \\
\text { Handan, Xingtai, } \\
\text { Hengshui } \\
\end{array}$ & $\begin{array}{c}\text { Shijiazhuang, } \\
\text { Hengshui, Handan, } \\
\text { Xingtai } \\
\end{array}$ \\
\hline $\begin{array}{l}\text { Nodes with } \\
\text { greater } \\
\text { weighted } \\
\text { degree }\end{array}$ & $\begin{array}{c}\text { Tianjin, Beijing, } \\
\text { Langfang, } \\
\text { Tangshan, } \\
\text { Baoding, } \\
\text { Shijiazhuang } \\
\end{array}$ & $\begin{array}{l}\text { Tianjin, Beijing, } \\
\text { Langfang, } \\
\text { Tangshan, Baoding, } \\
\text { Shijiazhuang }\end{array}$ \\
\hline $\begin{array}{l}\text { Nodes with } \\
\text { greater } \\
\text { weighted } \\
\text { In-Degree }\end{array}$ & $\begin{array}{c}\text { Langfang, Tianjin, } \\
\text { Beijing, Tangshan, } \\
\text { Baoding, } \\
\text { Cangzhou } \\
\end{array}$ & $\begin{array}{l}\text { Langfang, Tianjin, } \\
\text { Beijing, Tangshan, } \\
\text { Baoding, Cangzhou }\end{array}$ \\
\hline $\begin{array}{l}\text { Nodes with } \\
\text { greater } \\
\text { weighted } \\
\text { Out-Degree }\end{array}$ & $\begin{array}{c}\text { Tianjin, Beijing, } \\
\text { Shijiazhuang, } \\
\text { Tangshan, } \\
\text { Baoding, Xingtai }\end{array}$ & $\begin{array}{c}\text { Tianjin, Beijing, } \\
\text { Shijiazhuang, } \\
\text { Tangshan, Baoding, } \\
\text { Xingtai }\end{array}$ \\
\hline $\begin{array}{l}\text { Nodes with } \\
\text { greater } \\
\text { Closeness } \\
\text { Centrality }\end{array}$ & $\begin{array}{c}\text { Shijiazhuang, } \\
\text { Cangzhou, } \\
\text { Tangshan, } \\
\text { Baoding, Beijing }\end{array}$ & $\begin{array}{c}\text { Shijiazhuang, } \\
\text { Cangzhou, } \\
\text { Tangshan, } \\
\text { Langfang, Baoding, } \\
\text { Beijing }\end{array}$ \\
\hline
\end{tabular}




\begin{tabular}{|c|c|c|}
\hline $\begin{array}{c}\text { Nodes with } \\
\text { greater } \\
\text { Betweennes } \\
\text { s Centrality }\end{array}$ & $\begin{array}{c}\text { Tianjin, Beijing, } \\
\text { Shijiazhuang }\end{array}$ & $\begin{array}{c}\text { Tianjin, Beijing, } \\
\text { Shijiazhuang, } \\
\text { Baoding }\end{array}$ \\
\hline
\end{tabular}
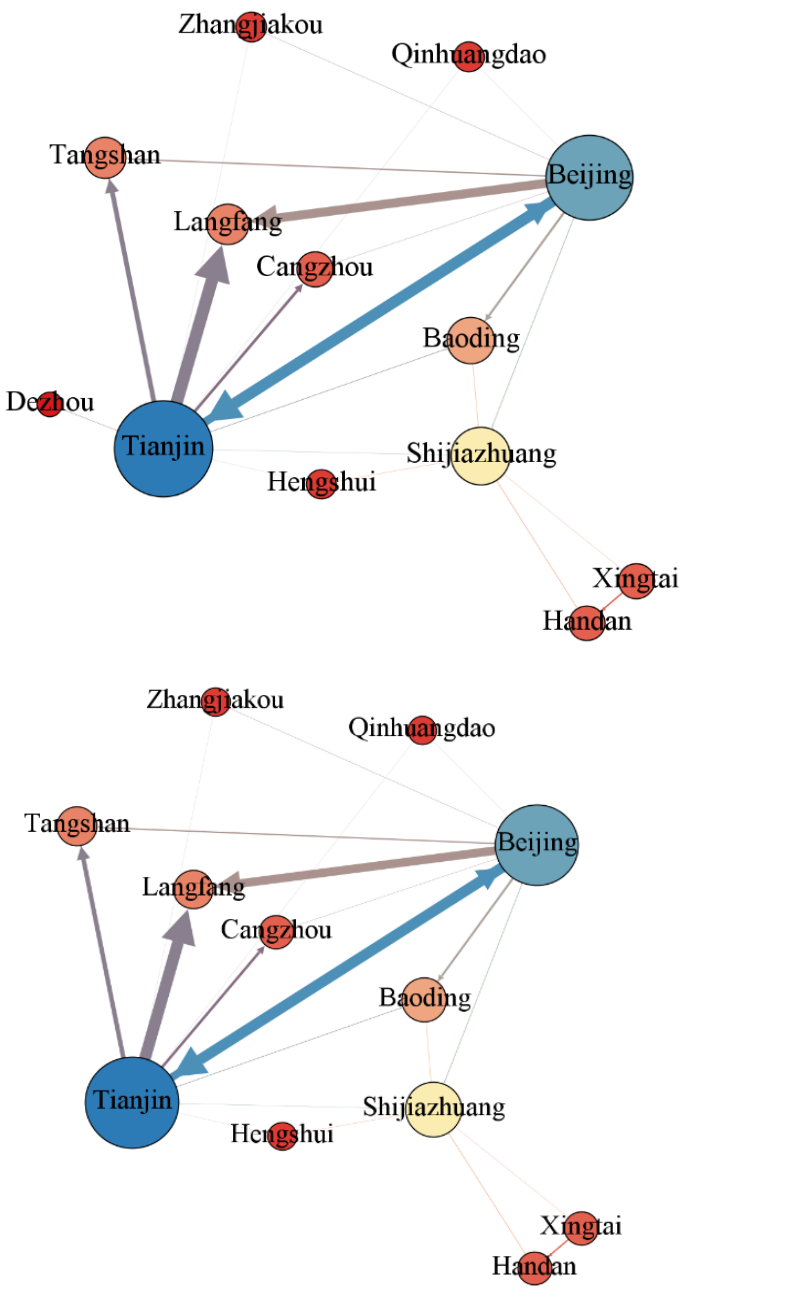

Fig. 4. (a) (a) Innovation-driven network graph of BeijingTianjin-Hebei urban agglomeration; (b) Innovation-driven network graph of Beijing-Tianjin-Hebei urban agglomeration (exclude Dezhou).

\section{Conclusion and discussion}

By properly defining and modeling, the social network model can describe the relationship between cities very well, which has a very good research and application character. In the future, we will acquire real population flow, economic cooperation, and innovation exchange data to instead the gravity model to improve accuracy. Beijing-Tianjin-Hebei Urban Agglomeration is the most concerned region in China nowadays. From the case study, we can draw,

Firstly, the traffic interaction network is closer than the economic correlation network and the innovationdriven network, and the economic correlation network is closer than the innovation-driven network. It indicates that the traffic integration develops better than the economic and the innovation integration, and the economic integration develops better than the innovation integration in some extent.

Secondly, Dezhou has the base to promote transportation integration in the greater Beijing-TianjinHebei region, however, it lacks the economic momentum and innovation driven. In order to promote development of Beijing-Tianjin-Hebei region, Dezhou should strengthen economic ties and innovation cooperation with other cities.

Thirdly, the three networks all have a high degree of centralization and a greater difference between cities, which is that Beijing, Tianjin and Shijiazhuang develop relatively well, Chende, Hengshui and Zhangjiakou relatively fall behind. As a result, Chende, Hengshui and Zhangjiakou should speed up development and expand cooperation. Beijing, Tianjin and Shijiazhuang should increase support efforts on Chende, Hengshui and Zhangjiakou. Chengde must increase the degree of innovation and communication to have a relation with others cities.

The author gratefully acknowledges the support of the National Natural Science Foundation of China (NSFC) (71403262; 91024010; 71503246), and the Youth Innovation Promotion Association Program of Chinese Academy of Sciences (2014139).

\section{References}

1. J. Peng, J.S. Wu, Y.Y. Jiang, M.T. Ye, Acta. Ecol. Sin, 26, 8(2006)

2. X.W. Chen, Int J Remote Sens, 23, 1(2002)

3. J.H. Huang, H.L. Lv, L.J. Wang, Geogr. Res, 33,3 (2014)

4. I. Makarova, R. Khabibullin, A. Belyaev, E. Bekyaev, V. Mavrin, Transport Problems, 8,2(2013)

5. P. Nijkamp, C.J.M. Bergh, F.J. Soeteman, World Bank Econ Rev, 4, suppl 1(1990)

6. G. Berger, J. Enviro. Policy Plann, 5,3(2003)

7. J. Scott, SNAM, 1,1(2011)

8. S. Wasserman, K. Faust, CS, 91, 435(1994)

9. T. Zhou, B.H. Wang, X.P. Han, M.S. Shang, J. Syst. Eng, 25,6(2010)

10. B.V. Carolan, Social network analysis and education: theory, methods \& applications, (2005).

11. Y.J. Wang, Y.G. Zong, L. Ouyang, C.Q. Ren, Areal Res. Dev, 30,6(2011)

12. T.J. Fik, G.F. Mulligan, Environ. Plann. A, 30, 8(1998)

13. W. Berentson, P. Nijkamp, Environ. Plann. B, 15, 4(1988)

14. Y.G. Chen, J.S. Liu, Geogr. Res, 21, 6(2002)

15. Y.H. Hou, Z.B. Liu, Z.G. Yue, China Soft Sci, 45,12(2009)

16. L.J. Zhao, Z.L. Zhao, Z. Chen, J. Sys. Manag, 21,1(2012)

17. A. Barrat, A.L. Barabasi, G. Caldarelli, R.P. Delos, A. Erzan, B. Kahng, EPJB, 38,2(2004) 
18. V.D. Blondel, J.L. Guillaume, R. Lambiotte, E. Lefebvre, J. Stat. Mech- Theory E, 10 (2008)

19. R. Lambiotte, J.C. Delvenne, M. Barahona, Physics, (2009).

20. D.J. Watts, AJ S, 105,2(1999)

21. U. Brandes, J. Math. Sociol, 25, 2(2001) 